\title{
Identifying Antioxidant Activities of Guava Fruit Using DPPH Method
}

\author{
Adita Silvia Fitriana \\ Pharmacy Study Program, Faculty of Health Science \\ Harapan Bangsa University \\ Purwokerto, Indonesia \\ aditasilvia@uhb.ac.id
}

\author{
Sri Royani \\ Chemistry Study Program, Faculty of Science and Technics \\ Harapan Bangsa University \\ Purwokerto, Indonesia \\ sriroyani@uhb.ac.id
}

\begin{abstract}
Antioxidant plays an important role in preventing degenerative diseases. One of fruits that has a potential antioxidant activity is guava. This research was aim to identify antioxidant activity of guava fruit. Potential antioxidant compounds in guava were extracted using sonicator, as a green extraction technique. DPPH (2,2-diphenyl-1-picrylhydrazyl) was used to determine antioxidant activity. Vitamin $C$ was used as a reference standard. The result showed that ethyl acetate extract of guava fruit has a high antioxidant activity. The presence of flavonoids, steroids, and tannins in ethyl acetate extract were predicted as a potential antioxidant compounds.
\end{abstract}

\section{Keywords: antioxidant, DPPH, green extraction, guava}

\section{INTRODUCTION}

Free radical is a reactive molecule that contain one or more unpaired electrons and initiating a chain reaction. Free radicals are beneficial to human body in moderate level. In high concentration, free radicals can damage the vital molecule in the body, such as DNA, carbohydrates, lipids, and proteins. These can cause some degenerative diseases i.e. cancer, diabetes mellitus, hypertension, heart failure, cataract and retinal disease, renal failure, Alzheimer's, etc [1], [2].

Antioxidant is a molecule that counteracting the toxic effect of free radicals by inhibiting the oxidative chain reaction. Fruit and vegetables are potential source of exogenous antioxidant. Some studies stated that carrot [3], tomato [4], namnam [5], doum fruit [6], noni (Morinda Citrifolia) [7], orange [8], blueberry [9], and guava have potent antioxidant activity [10].

Guava has potential antioxidant compounds such as phenolic and flavonoid compounds, ascorbic acid, carotenoids, and lycopene [10]-[12]. Solvent and extraction technique influence the bioactive compounds extracted. Ethyl acetate can extract polyphenols, flavonoids, and tannin as potential antioxidant compounds from walnut green husk [13]. Some studies exhibited the antioxidant activity of ethyl acetate extract from plants and mushroom [14]-[17].

Various extraction method have been used for extracting antioxidant. Ultrasonic extraction is one of the nonconventional methods that are energy-efficient and economically sustainable [2]. Reference [18] proved the ultrasonic extraction is the best technique to extract antioxidant from guava. Therefore, in this study we used sonicator as an ultrasonic extractor to extract bioactive compounds from guava fruit.

In this research, we determine the antioxidant activity of ethyl acetate extract of guava fruit. We also investigate the phytochemical properties of the extracts to predict the bioactive compounds. Phytochemical screening test were identified by the precipitate formation or the color change.

\section{METHODOLOGY}

A. Chemicals

DPPH (2,2-diphenyl-1-picrylhydrazyl) was purchased from Sigma-Aldrich and Vitamin C (IPI 50 mg) was from PT. Supra Ferbindo Farma. Methanol p.a., Ethyl acetate p.a., and hexane p.a. were purchased from Smartlab.

\section{B. Plant Material}

Pink flesh guava fruit (Psidium guajava, Linn) was obtained from the traditional market in Purwokerto, Central Java, Indonesia.

\section{Preparation of Extract}

The pink flesh guava fruits were washed and crushed to produce uniform slurry without peeling the skin. The slurry sample were extracted using sonicator with ethyl acetate at room temperature. The extraction process was carried out for one hour. The cloudy extracts were centrifuge for 10 minutes at 3,000 rpm. Then, using vacuum rotary evaporator the clear supernatant was concentrated at $50-65^{\circ} \mathrm{C}$.

\section{Phytochemical Screening}

The phytochemical screening was carried out to identify flavonoids, saponins, tannins, triterpenoids and steroids content. The presence of these metabolites was identified by the precipitate formation and the color change or intensity.

\section{E. Antioxidant Activity}

Briefly, $0.1 \mathrm{mM}$ DPPH solution was prepared in methanol solvent. About $2 \mathrm{~mL}$ of DPPH solution was mixed with $2 \mathrm{~mL}$ of methanolic guava extract solution $(0.01-0.13 \mathrm{mg} / \mathrm{mL})$. The mixture was incubated at room temperature and placed in a dark room. After 30 
minutes, the antioxidant activity was determined by measuring the absorbance level using UV-Vis spectrophotometer at $515.5 \mathrm{~nm}$. The absorbance data then put in this equation below to calculate the percent inhibition.

$$
\text { Inhibitory activity }(\%)=\frac{\text { Abs control-Abs sample }}{\text { Abs control }} \times 100 \%
$$

Furthermore, the $\mathrm{IC}_{50}$ values were determined to identify the antioxidant activity by plotting the percent inhibition versus inhibitory concentration.

\section{FINDINGS AND DISCUSSION}

\section{A. Phytochemical Study}

Phytochemical analysis of ethyl acetate extract of guava fruit are showed the presence of flavonoids, steroids, and tannins. Flavonoids were confirmed using magnesium powder and hydrochloric acid. The formation of reddishblack solution indicated the positive reaction. Terpenoids and steroids identification were conducted using LiebermanBurchard reagent. A blue or green color formation in solution expressed the presence of steroids. Tannins were verified by ferric chloride test. A green, purple, blue or black color developed indicating the presence of tannins.

TABLE I. PHYTOCHEMICAL ANALYSIS
\begin{tabular}{|c|c|}
\hline Phytochemicals & Result \\
\hline Flavonoids & + \\
\hline Saponins & - \\
\hline Tannins & + \\
\hline Triterpenoids & - \\
\hline Steroids & + \\
\hline
\end{tabular}

\section{B. Antioxidant Activity}

In this research, DPPH method was used to determine the antioxidant activity of guava fruit extract by measuring the fruit extract abilities to donate hydrogen atom to the DPPH radical. The more hydrogen atom donated to DPPH radical, the greater the color change of DPPH radical solution, from purple to yellow color [19]. The absorbance of DPPH solution was monitored by UV-Vis

Spectrophotometer. Then, the absorbance was used to calculate the percent inhibition.

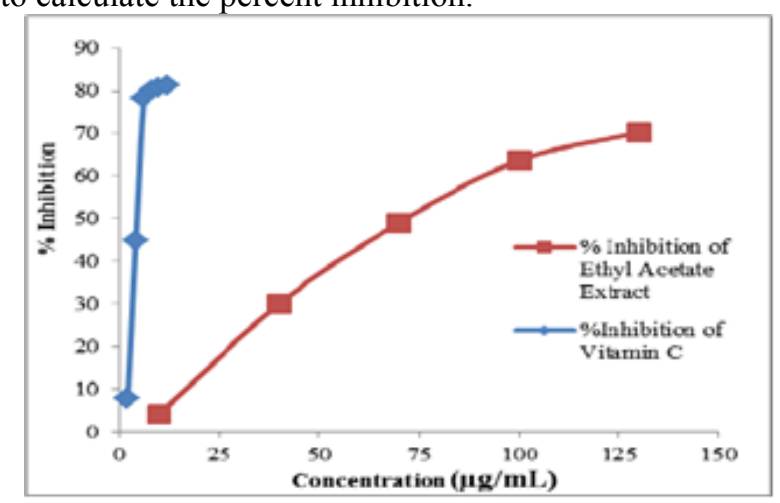

Fig. 1. Percent Inhibition of Vitamin C and Ethyl Acetate Extract of Guava Fruit
Picture 1 showed that the extract concentration is proportional to the percent inhibition. It means, the greater the extract concentration, the more antioxidant in the extract that can reduce free radical activity [20]. Vitamin $\mathrm{C}$ as a reference standard has the same inhibition pattern with guava extract. The percent inhibition of Vitamin $\mathrm{C}$ was higher than ethyl acetate extract. Based on the linear regression calculation, the IC50 of ethyl acetate extract of guava fruit was 81.92 $\mu \mathrm{g} / \mathrm{mL}$.

Antioxidant activity of guava fruit is higher than other fruits, such as banana, carrot, pineapple, pawpaw (papaya) tomato, watermelon, and orange with the $\mathrm{IC}_{50}$ were $181.86 \mu \mathrm{g} / \mathrm{mL}, 228.05 \mu \mathrm{g} / \mathrm{mL}, 311.81 \mu \mathrm{g} / \mathrm{mL}$, $251.51 \mu \mathrm{g} / \mathrm{mL}, 277.43 \mu \mathrm{g} / \mathrm{mL}, 217.56 \mu \mathrm{g} / \mathrm{mL}$, and $187.30 \mu \mathrm{g} / \mathrm{mL}$, respectively [21]. Furthermore, [22] reported that antioxidant activity of watermelon, papaya, pear, and jackfruit are lower than guava.

The antioxidant activity of ethyl acetate extract of guava fruit may be due to the presence of phytochemicals i.e. flavonoids, steroids, and tannins. Some studies have shown that flavonoids and tannins are the potential antioxidant compounds. The high flavonoids contents in the extract exhibited a high antioxidant activity [23], [24]. Furthermore, tannins content in $P$. amarusare enhanced the antioxidant activity [25].

\section{CONCLUSION}

Guava fruit can be used as an alternative source of antioxidant. Ethyl acetate extract of guava fruit showed a high antioxidant activity. This extract contains some phytochemicals such as flavonoids, steroids, and tannins. These components are predicted as a potential antioxidant compounds.

\section{ACKNOWLEDGMENT}

The author would like to thank The Dwi Puspita Foundation and Harapan Bangsa University for the financial support.

\section{REFERENCES}

[1] P. Sailaja Rao, S. Kalva, A. Yerramilli, and S. Mamidi, "Free radicals and tissue damage: role of antioxidants," Free Radicals Antioxidants, vol. 1, no. 4, pp. 2-7, 2012.

[2] D. P. Xu et al., "Natural antioxidants in foods and medicinal plants: Extraction, assessment and resources," Int. J. Mol. Sci., vol. 18, no. 1, pp. 20-31, 2017.

[3] A. S. Potter, S. Foroudi, A. Stamatikos, B. S. Patil, and F. Deyhim, "Drinking orange juice increases total antioxidant status and decreases lipid peroxidation in adults," Nutr. J., vol. 10, no. 96, pp. 1-6, 2011.

[4] Novelina, N. Nazir, and M. R. Adrian, "The improvement lycopene availability and antioxidant activities of Tomato (Lycopersicum Esculentum, Mill) jelly drink," in Agriculture and Agricultural Science Procedia, 2016, vol. 9, pp. 328-334. 
[5] A. Adawiah, D. Sukandar, and A. Muawanah, "Aktivitas antioksidan dan kandungan komponen bioaktif sari buah Namnam," J. Kim. Val., vol. 1, no. 2, pp. 130-136, 2015.

[6] B. Hsu, I. M. Coupar, and K. Ng, "Antioxidant activity of hot water extract from the fruit of The Doum Palm, Hyphaene thebaica," Food Chem., vol. 98, no. 2, pp. 317-328, 2006.

[7] Z. M. Zin, A. Abdul-Hamid, and A. Osman, "Antioxidative activity of extracts from Mengkudu (Morinda citrifolia L.) root, fruit and leaf," Food Chem., vol. 78, pp. 227-231, 2002.

[8] I. Fidrianny, M. Harnovi, and M. Insanu, "Evaluation of antioxidant activities from various extracts of sweet orange peels using DPPH, FRAP assays and correlation with Phenolic, Flavonoid, Carotenoid content," Asian J. Pharm. Clin. Res., vol. 7, no. 3, pp. 186-190, 2014.

[9] X. Li, H. Liu, L. Lv, H. Yan, and Y. Yuan, "Antioxidant activity of blueberry anthocyanin extracts and their protective effects against acrylamide-induced toxicity in HepG2 cells," Int. J. Food Sci. Technol., vol. 53, pp. 147-155, 2018.

[10] L. Y. Yan, L. T. Teng, and J. TeeJing, "Antioxidant properties of Guava fruit: comparison with some local fruits," Sunw. Acad. J. 3, vol. 03, pp. 9-20, 2006.

[11] K. H. Musa, A. Abdullah, and V. Subramaniam, "Flavonoid profile and antioxidant activity of pink Guava," Sci. Asia, vol. 41, pp. 149 154,2015

[12] F. Priam, O. Marcelin, R. Marcus, L.-F. Jô, and E. J. Smith-Ramin, "Lycopene extraction from Psidium guajava L. and evaluation of its antioxidant properties using a modified DPPH test," IOSR J. Environ. Sci. Toxicol. Food Technol., vol. 11, no. 4, pp. 67-73, 2017.

[13] Q. Zhang, "Effects of Extraction Solvents on Phytochemicals and Antioxidant Activities of Walnut (Juglans Regia L.) Green Husk Extracts," Eur. J. Food Sci. Technol., vol. 3, no. 5, pp. 15-21, 2015.

[14] M. H. Abdille, R. P. Singh, G. K. Jayaprakasha, and B. S. Jena, "Antioxidant Activity of The Extracts from Dillenia indica Fruits," Food Chem., vol. 90, pp. 891-896, 2005.

[15] B. S. F. Bazzaz, M. H. Khayat, S. A. Emami, J. Asili, A. Sahebkar, and E. J. Neishabory, "Antioxidant and Antimicrobial Activity of Methanol, Dichloromethane, and Ethyl Acetate Extracts of Scutellaria litwinowii," Sci. Asia, vol. 37, pp. 327-334, 2011.
[16] R. Singh, S. Singh, S. Kumar, and S. Arora, "Evaluation of Antioxidant Potential of Ethyl Acetate Extract/Fractions of Acacia auriculiformis A . Cunn," Food Chem. Toxicol., vol. 45, pp. 12161223, 2007.

[17] N. I. Ratnaningtyas, P. Purnomowati, E. S. Purwati, A. T. Septiana, N. Ekowati, and A. Supriyadi, "Antioxidant Potential of Ethanol and Ethyl Acetat Extract of Ganoderma sp. Mycelium," Biosaintifika, vol. 10, no. 1, pp. 87-94, 2018.

[18] K. H. Musa, A. Abdullah, K. Jusoh, and V. Subramaniam, "Antioxidant Activity of Pink-Flesh Guava (Psidium guajava L.): Effect of Extraction Techniques and Solvents," Food Anal. Methods, vol. 4, no. 1, pp. 100-107, 2011.

[19] C. Rekha et al., "Ascorbic acid, total phenol content and antioxidant activity of fresh juices of four ripe and unripe Citrus fruits," Chem. Sci. Trans., vol. 1, no. 2, pp. 303-310, 2012.

[20] N. Widyasanti, Asri; Rohdiana, Dadan; Ekatama, "Aktivitas antioksidan ekstrak teh putih (Camellia sinensis) dengan metode DPPH (2,2 Difenil-1-Pikrilhidrazil)," Fortech, vol. 1, no. 1, pp. 1-9, 2016.

[21] G. Oboh, A. O. Ademosun, M. Akinleye, O. S. Omojokun, A. A. Boligon, and M. L. Athayde, "Starch composition, glycemic indices, phenolic constituents, and antioxidative and antidiabetic properties of some common tropical fruits," J. Ethn. Foods, vol. 2, no. 2, pp. 6473, 2015.

[22] K. S. Jumuna, C. K. Ramesh, T. R. Srinivasa, and K. L. Raghu, "Comparative studies on DPPH and reducing power antioxidant properties in aqueous extracts of some common fruits," J. Pharm. Res., vol. 3, no. 10, pp. 2378-2380, 2010.

[23] Y. M. Evary and A. M. Nur, "Antioxidant and antidiabetes capacity of hexane, ethyl acetate and ethanol extracts of Durio zibethinus Murr. root," Pharmacogn. J., vol. 10, no. 5, pp. 937-940, 2018.

[24] Q. D. Do et al., "Effect of extraction solvent on total phenol content, total flavonoid content, and antioxidant activity of Limnophila aromatica," J. Food Drug Anal., vol. 22, no. 3, pp. 296-302, 2014.

[25] W. Ujwala, S. Vijender, and A. Mohammad, "In-vitro antioxidant activity of isolated tannins of alcoholic extract of dried leaves of Phyllanthus Amarusschonn and Thonn," Int. J. Drug Dev. Res., vol. 4, no. 1, pp. 274-285, 2012. 